\title{
Sociocultural dimension of parents of premature infants discharged from a Neonatal Intensive Care Unit
}

\author{
Dimensão sociocultural de pais de prematuros egressos de Unidades de Terapia Intensiva \\ Neonatal
}

\author{
Dimensión sociocultural de padres de prematuros egresos de Unidades de Cuidados \\ Intensivos Neonatales
}

Isis Vanessa Nazareth ${ }^{1}$, Inês Maria Meneses dos Santos ${ }^{2}$

This study aimed at identifying and analyzing the social and cultural dimensions of parents of premature infants discharged from neonatal intensive care units. It is a qualitative and descriptive study, based on ethno-nursing and in the Theory of Diversity and Universality Cultural Care with 12 participants. The setting was a university hospital in the city of Rio de Janeiro, RJ, Brazil. Data collection occurred between November, 2012 and April, 2013, through a social economic and cultural questionnaire and from the observation, participation and reflection. The analysis based on ethno-nursing and on the use of Atlas-ti software allowed to find the analytical category: the sociocultural structure of parents of premature infants discharged from a neonatal intensive care unit. Results should be used to promote a culturally relevant care and respecting the popular knowledge of parents while taking care of the children discharged from neonatal intensive care units.

Descriptors: Neonatal Nursing; Transcultural Nursing; Infant, Premature; Child Health.

Objetivou-se identificar e analisar as dimensões culturais e sociais de pais de prematuros egressos de unidades de terapia intensiva neonatal. Estudo qualitativo e descritivo, baseado na etnoenfermagem e na Teoria da Diversidade e Universalidade do Cuidado Cultural, com 12 participantes. 0 cenário foi um hospital universitário da cidade do Rio de Janeiro, RJ, Brasil. A coleta de dados ocorreu entre novembro/2102 e abril/2013, através de questionário socioeconômico-cultural e da observação-participação-reflexão. Análise baseada na etnoenfermagem e utilização do software atlas-ti permitiram encontrar a categoria analítica: a estrutura sociocultural de pais de egressos de unidades de terapia intensiva neonatal. Resultados devem ser usados na promoção de uma assistência culturalmente pertinente e que respeite o saber popular de pais ao cuidarem dos filhos egressos de unidades de terapia intensiva neonatal.

Descritores: Enfermagem Neonatal; Enfermagem Transcultural; Prematuro; Saúde da Criança.

Los objetivos fueron identificar y analizar las dimensiones sociales y culturales de padres de prematuros egresos de unidades de cuidados intensivos neonatales. Estudio cualitativo, descriptivo, basado en etnoenfermería y en la Teoría de la Diversidad y Universalidad del Cuidado Cultural, con 12 participantes. El escenario fue un hospital universitario de la ciudad de Río de Janeiro, RJ, Brasil. La recolección de datos ocurrió entre entre noviembre/2102 y abril/2013, a través de cuestionario socioeconómico cultural y observación-participación-reflexión. Análisis basado en etnoenfermería y utilización del software atlas-ti permitió encontrar la categoría analítica: la estructura sociocultural de padres de egresos de unidades de cuidados intensivos neonatales. Resultados deben ser utilizados para promover una atención culturalmente pertinente y que respecte el saber popular de padres al cuidar de hijos egresos de unidades de cuidados intensivos neonatales.

Descriptores: Enfermería Neonatal; Enfermería Transcultural; Prematuro; Salud del Niño.

\footnotetext{
${ }^{1}$ Universidade Federal do Rio de Janeiro. Rio de Janeiro, RJ, Brazil.

${ }^{2}$ Universidade Federal do Estado do Rio de Janeiro. Rio de Janeiro, RJ, Brazil.

Corresponding author: Inês Maria Meneses dos Santos

Av. Pasteur, 296 - Urca - CEP: 22290-240. Rio de Janeiro, RJ, Brazil. E-mail: inesmeneses@gmail.com
} 


\section{Introduction}

This study has as thematic the parental culture. Culture is conceptualized as the values, beliefs, rules and ways of living of a specific group, learned, shared and transmitted and that guide their thoughts, decisions, and actions in a standardize manner and frequently between generation $\mathbf{s}^{(1-2)}$.

The cultural factors which involve the family structure are concerning the understanding that the parents have ideas on the care of their children when they are still intrauterine, this is explicit in the way how they imagine directing their bringing up, control the behavior and influence for a good future ${ }^{(2-3)}$.

Although the idealized child is lost by the parents after the premature delivery, the way how one takes care of the other, in this case parents with premature infant. Perceiving the disease or the deficiency depends besides other factors, on the cultural dimensions and on the social structures of the subject in the context involved, once they push the subjects to construct their attitudes, reflecting their choices and consequently in the way they pass their vision of world between generations, especially for their children ${ }^{(2-3)}$.

Although it is evident that the parental cultural practices permeate and influence the development of healthy children, as well as the children with biological alterations, little is known on their specificities (practices typically used in the care of the children) and their influences ${ }^{(2)}$. When the life of the child goes on at home, little is known regarding the reality of the family that will take care of the infant, and also it is not known about the cognitive abilities of the mothers and how they render care to these children ${ }^{(1-3)}$.

Understanding that the parents of premature infants form a cultural group that must be valued for having particular experiences which provide meaning to the human expressions, social interpretation and interactions, it becomes important to make researches involving the cultural and social factors of parents of premature infants discharged from a
Neonatal Intensive Care Unit taking in consideration the several social and cultural dimensions relating them to elements of the dynamics of the context of the child development, understanding the aspects of behavior (family practices) and the representations (social and cultural dimensions) as inseparable of the phenomenon ${ }^{(1-3)}$.

Considering that the environmental context of parents with children who were born prematurely and are discharged from a Neonatal Intensive Care Unit sharing knowledge and values, the present investigation has as objective of the study to identify and analyze the social and cultural factors of parents of premature infants discharged from a Neonatal Intensive Care Unit.

\section{Method}

It is a descriptive study of qualitative nature based on the method of the ethno-nursing and on the Theory of Diversity and Universality of Cultural Care of the scholar Madeleine Leininger. It was made in a university hospital of Rio de Janeiro, Brazil. There were 12 people as subjects, being nine mothers of premature infants discharged from a Neonatal Intensive Care Unit, two couples and one father. The participation of only the father was caused by the maternal death at the moment of delivery.

The data collection occurred between the months of November, 2012 to April, 2013. The criteria of inclusion were mothers and/or fathers of children until 24 months of age; born prematurely of both sexes; with permanence of hospitalization for a period equals or superior to seven days at the Neonatal Intensive Care Unit, and living in the family environment. The criteria of exclusion were children living in shelters, whose care was taken by other people.

To make the data collection feasible it was necessary to develop the following trainers (facilitators): The trainer (model) Sunrise (social economic and cultural questionnaire) and the trainer 
observation-participation-reflection ${ }^{(2)}$.

The analysis of qualitative data becomes an intensive activity requiring from the researcher creativity, reflection, sensibility and hard work, once it does not happen in a linear manner, but in a complex and instigating manner for anyone $\mathrm{e}^{(4)}$. Based on this premise, this analysis was based on the ethno-nursing being divided in four phases.

In phase 1 there was the collection, description, register and beginning of the analysis of the data related to the objectives and domain of inquiry, in this case parental culture. In phase 2 there was the identification and categorization of the narrators from the use of the Atlas-ti (Qualitative Research and Solutions - Non-numeric Unstructured Data - índex, Searching and Theorizing) software. This software is used for the analysis of the qualitative data allowing the storage, codification and integration of a large quantity of complex data, and it also makes possible to gather data and provide relevant interpretations ${ }^{(5)}$.

In phase 3 the contextual analysis was made and in the last phase (4) the synthesis of thinking results of interpretation and creative formulation of data of the previous phases were required. This phase allowed, through the Atlas-ti software, the creation the group: Post-discharged/Home environment/ Family (Figure 1).

\begin{tabular}{|l|l|}
\hline \multicolumn{2}{|c|}{ Group: Post-discharged/Home environment/Family } \\
\hline Family support & $\begin{array}{l}\text { Financial difficulty/high cost } \\
\text { of the milk }\end{array}$ \\
\hline $\begin{array}{l}\text { Lack of the mother/father of } \\
\text { the baby }\end{array}$ & $\begin{array}{l}\text { Discharge/learn to care/ } \\
\text { know the child }\end{array}$ \\
\hline Stop working & Restrict visit/cannot kiss/ \\
\hline Lack of family help & $\begin{array}{l}\text { Go back to work/ children in } \\
\text { the nursery/ caregivers }\end{array}$ \\
\hline $\begin{array}{l}\text { As if the infant were not } \\
\text { premature }\end{array}$ & Nights without sleeping \\
\hline $\begin{array}{l}\text { Nobody knows me better } \\
\text { than my son }\end{array}$ & $\begin{array}{l}\text { Discrimination due to excess } \\
\text { of care }\end{array}$ \\
\hline Opinion of others & Take care alone/he needs me \\
\hline Insecurity/fear of breaking & $\begin{array}{l}\text { Care is bigger for being pre- } \\
\text { mature/small }\end{array}$ \\
\hline $\begin{array}{l}\text { Cleaning and adaptation } \\
\text { of the house/cleaning the } \\
\text { babies utensils }\end{array}$ & $\begin{array}{l}\text { Teaching through genera- } \\
\text { tions/beliefs/superstition }\end{array}$ \\
\hline God: Affection, lesson, will & $\begin{array}{l}\text { Change of life/he is everything } \\
\text { in my life }\end{array}$ \\
\hline
\end{tabular}

Figure 1 - Atlas-ti: group1 - Post-discharged/Home environment/Family
This research was submitted to the Committee of Ethics and Research of the Universidade Federal do Rio de Janeiro, with ordinance approved under protocol no. 109.934. The participants signed the Informed Consent Form, the anonymity was guaranteed as well as the desistance at any time without harm to the participant. In order to guarantee the anonymity of the interviewees we substituted their names by the letter ' $\mathrm{P}$ ' followed by a number, for example 'P1'.

\section{Results}

Descriptions were made which present the dimension of the social and cultural structure of nine mothers (P1 a P9), two couples (P10 e P11) and one father (P3) involved in the environmental context.

The factors related to the ways of living: economic and educational (Figure 2).

Regarding schooling, there were parents who reported having from incomplete grade to incomplete university. When questioned on the interruption of school, pregnancy was pointed as the main obstacle for permanence in the institution.

Families (P11, P5, P2, P3) with reduced financial resources were observed and, they are exactly the ones who reported repeated hospitalizations and frequent diseases of the children.

The second factor observed was the technologic one and the religion and philosophy factor (Figure 3). To observe the technology in society it is necessary to know the social environment where these people live ${ }^{(1)}$, highlighting technology, such as: electricity; supply of treated water and sewage system (basic sanitation), means of public transportation (bus), private (car) or alternative (van). They were also inquired on the devices acquired after the hospital discharge of the premature infant. Another item analyzed, refers to the religion in which the participants were brought up and the one they follow currently. These are relevant data for the studies focused in the social and cultural matter. 


\begin{tabular}{|c|c|c|c|c|c|c|}
\hline Participants & $\begin{array}{l}\text { No. of people } \\
\text { in the house }\end{array}$ & $\begin{array}{l}\text { No. of } \\
\text { rooms }\end{array}$ & $\begin{array}{l}\text { Family } \\
\text { income }\end{array}$ & $\begin{array}{l}\text { Source of } \\
\text { income }\end{array}$ & Schooling/Teaching & $\begin{array}{c}\text { Reason for interrupting } \\
\text { studies }\end{array}$ \\
\hline P1 & 10 & 5 & 1,100 & Couple, sister & Complete high school & Pregnancy \\
\hline $\mathrm{P} 2$ & 4 & 3 & 370 & Own income & Complete grade school & Pregnancy \\
\hline P3 & 2 & 1 & 470 & Own income & Complete grade school & Need to work \\
\hline $\mathrm{P} 4$ & 9 & 6 & 1,000 & $\begin{array}{l}\text { Parents, } \\
\text { brother }\end{array}$ & Incomplete high school & - \\
\hline P5 & 3 & 3 & 450 & Partner & Incomplete grade school & School expulsion \\
\hline P6 & 8 & 4 & 670 & Mother & Incomplete grade school & Option \\
\hline P7 & 5 & 4 & 640 & Partner & Incomplete high school & Pregnancy \\
\hline P8 & 8 & 3 & 670 & Partner & Incomplete high school & Pregnancy \\
\hline P9 & 6 & 4 & 950 & Couple & Incomplete grade school & Need to work \\
\hline P10 & 7 & 4 & 800 & Partner & Incomplete high school & Pregnancy \\
\hline P11 & 5 & 6 & 470 & Partner & Complete high school & Pregnancy \\
\hline $\mathrm{P} 12$ & 2 & 3 & 690 & Partner & Incomplete university & Pregnancy \\
\hline
\end{tabular}

Figure 2 - Social economic cultural profile; cultural factors of the way of living: economic and educational

\begin{tabular}{|c|c|c|c|c|c|c|}
\hline Participants & Electrecity & $\begin{array}{c}\text { Basic } \\
\text { sanitation }\end{array}$ & $\begin{array}{c}\text { Means of } \\
\text { transport }\end{array}$ & Devices aquired ${ }^{4}$ & $\begin{array}{c}\text { Religion in which } \\
\text { the participants } \\
\text { were brought up }\end{array}$ & $\begin{array}{c}\text { Current } \\
\text { religion }\end{array}$ \\
\hline P1 & Yes & Yes & Bus & Thermometer & Catholic & Catholic \\
\hline P2 & No & No & Bus & Nebulizer and thermometer & Protestant & None \\
\hline P3 & Yes & Yes & Bus, van & $\begin{array}{c}\text { Thermometer, sound } \\
\text { equipment, blender, iron } \\
\text { and DVD player }\end{array}$ & Protestant \\
\hline P4 & Yes & Yes & Bus, car & Thermometer & Protestant & None \\
\hline P5 & No & No & On foot & Nebulizer and thermometer & Catholic & None \\
\hline P6 & Yes & Yes & Bus & Thermometer & Catholic & Non-practicing \\
catholic
\end{tabular}

${ }^{1}$ Paid for electricity; ${ }^{2}$ Paid for water supply; ${ }^{3}$ Most used means of transportation; ${ }^{4}$ Bough for the use of the child

Figure 3 - Social economic cultural profile: Technological factors and religion factor and philosophy 
Regarding the way of living factor, Figure 4 presented the day and night habits of the father or the mother of the premature infants, which are necessary for the understanding of the family dynamics in the whole context.

\begin{tabular}{|c|c|c|}
\hline Identifi- & Day habits & Night habits \\
\hline P1 & $\begin{array}{l}\text { Mother: Works } \\
\text { Child: Nursery, physiotherapy }\end{array}$ & $\begin{array}{l}\text { Mother: Household chores } \\
\text { Child: Irregular sleep }\end{array}$ \\
\hline P2 & $\begin{array}{l}\text { Mother: Works } \\
\text { Child: Under the care of the } \\
\text { aunt }\end{array}$ & $\begin{array}{l}\text { Mother: Household chores } \\
\text { Child: Irregular sleep }\end{array}$ \\
\hline P3 & $\begin{array}{l}\text { Father: Work's } \\
\text { Child: Under the care of the } \\
\text { nanny, sleeps }\end{array}$ & $\begin{array}{l}\text { Father: Household chores } \\
\text { Child: Irregular sleep }\end{array}$ \\
\hline P4 & $\begin{array}{l}\text { Mother: Goes to school } \\
\text { Child: Under the care of the } \\
\text { grandparents }\end{array}$ & $\begin{array}{l}\text { Mother: Goes out with the } \\
\text { partner } \\
\text { Child: Irregular sleep }\end{array}$ \\
\hline P5 & $\begin{array}{l}\text { Mother: Household chores } \\
\text { Child: Sleeps and watches TV }\end{array}$ & $\begin{array}{l}\text { Mother: Good standard of } \\
\text { sleep } \\
\text { Child: Sleeps the whole } \\
\text { night }\end{array}$ \\
\hline P6 & $\begin{array}{l}\text { Mother: Household chores } \\
\text { Child: Sleeps in the morning } \\
\text { and in the afternoon }\end{array}$ & $\begin{array}{l}\text { Mother: Takes care of the } \\
\text { children, wakes up in the } \\
\text { morning every three hours } \\
\text { Child: Irregular sleep }\end{array}$ \\
\hline P7 & $\begin{array}{l}\text { Mother: Household chores, } \\
\text { sleeps } \\
\text { Child: Sleeps }\end{array}$ & $\begin{array}{l}\text { Mother: Does not sleep to } \\
\text { take care of the child } \\
\text { Child: Irregular sleep }\end{array}$ \\
\hline P8 & $\begin{array}{l}\text { Mother: Household chores } \\
\text { Child: Sleeps }\end{array}$ & $\begin{array}{l}\text { Mother: Studying with } \\
\text { children } \\
\text { Child: Sleeps at } 10 \text { p.m. }\end{array}$ \\
\hline P9 & $\begin{array}{l}\text { Mother: Works } \\
\text { Child: Under the care of aunts }\end{array}$ & $\begin{array}{l}\text { Mother: Household chores } \\
\text { Child: Good standard of } \\
\text { sleep }\end{array}$ \\
\hline P10 & $\begin{array}{l}\text { Mother: Household chores } \\
\text { Child: Sleeps in the afternoon }\end{array}$ & $\begin{array}{l}\text { Mother: Takes care of the } \\
\text { children } \\
\text { Child: Good standard of } \\
\text { sleep }\end{array}$ \\
\hline P11 & $\begin{array}{l}\text { Mother: Household chores } \\
\text { Child: Under the care of the } \\
\text { grandmother }\end{array}$ & $\begin{array}{l}\text { Mother: Takes care of the } \\
\text { child } \\
\text { Child: Good standard of } \\
\text { sleep }\end{array}$ \\
\hline P12 & $\begin{array}{l}\text { Mother: Household chores } \\
\text { Child: Sleeps in the afternoon }\end{array}$ & $\begin{array}{l}\text { Mother: Goes to church } \\
\text { Child: Irregular sleep }\end{array}$ \\
\hline
\end{tabular}

Figure 4 - Social economic cultural profile: way of living factor

In the way of living factor it was observed that during the day three mothers and the father worked outside, and the other women are busy with household chores in their own house and one attends school. Regarding the children, six have alternative care during the day, one stays in the nursery, one is under the responsibility of the nanny and four are under the parents' care.

After the results presented in the group Postdischarged/Home environment/Family (Figure 1) and the Figures (two to four) an analytical category was codified: The social cultural structure of the parents of the infants discharged from Neonatal Intensive Care Unit.

\section{Discussion}

The analysis of the first level of the Sunrise Model of the Theory of Diversity and universality of the cultural care favors the reading of how the ways of life influence in the care and the state of health of subjects, groups, families and institutions considering the social and cultural aspects which, in turn, push the subjects to construct their attitudes, reflecting their choices and consequently in the way they pass their vision of the world between generations, especially for the children ${ }^{(1-2)}$.

\section{Analytical category: The social cultural structure of the parents of premature infants discharged from a Neonatal Intensive Care Unit}

It is noticed that most children live in houses with few rooms, sharing the area with until ten people, which favors a multifaceted every day, marked by conflicts and embarrassing circumstances. It is also highlighted that the children are exposed to insalubrity, once eight mothers reported to live in slums where the houses are together one to the other, which impedes adequate ventilation and sunlight, factors of risks for respiratory diseases ${ }^{(6)}$.

Cases like these, whose families are numerous and live in reduced areas, establish the dilution of the income and consequent social instability. The income of a family has a considerable weight in the way the children are taken care. It is the economic power 
which establishes, among other things, the power of buying food, clothing and medicine for the children. These aspects directly impact in the quality of the child life and their families ${ }^{(2,7)}$.

The small available room makes the children sleep together with the parents, especially in houses with more than one couple, as reported by three women. Other two mothers reported to put their children to sleep in the baby stroller, and the father reported using a mattress on the floor for the child to sleep.

It was observed that seven of the 12 interviewed women depended on the income of other members of the family whether they were partners, father, mother, aunt or brother. Four women and father raised their children with a monthly income bellow one minimum age considering that the minimum wage at the time of the interview was $\mathrm{R} \$ 680.00$ (six hundred and seventy eight reals).

The situation of extreme family poverty can generate the early insertion of the children in the work marked providing them with the sense of responsibility out of their time ${ }^{(7-9)}$. A vicious circle is created, which goes through generations and perpetuates the social exclusion of the poor children and their families. These data, are not the only ones and they are not even immune to distortions, but they serve as one more element in the process of appreciation of the problems in establishing priorities for the mobilization of resources and political will, in the decentralization and municipalization of the policies and services destined to childhood ${ }^{(7-9)}$.

This research also gathered information on the schooling of the participants, an important and influencing datum in the care of the children $^{(1)}$. There were participants with low schooling and this factor can cause a situation of vulnerability in the children in the first part of their early childhood, once the time of study is intimately related to the cognitive abilities which are used to stimulate their children. The schooling of the parents conditions the chances of schooling of their children and the cultural ambience of the family itself $f^{(8)}$. The maternal schooling has an impact on the cognitive development of children though factors such as the organization of the environment, expectations and parental practices, experiences with materials facing cognitive stimulation and the variation of daily stimulation ${ }^{(8-9)}$.

Having electricity in the house is an indicator of a technological factor in a society. Participants, which live in communities without infrastructure such as water supply, sewage system, paved road, public lighting, were interviewed. When questioned on light at home, everyone answered to have it, but four of them reported not paying for electricity and are supplied through illicit connection, and they also reported to live in precarious constructions located in risk areas.

The vulnerability of the health of the families who have premature infants is also reflected through the lack of a net of supply of treated water and a sewage system which lead to terrible conditions of cleanness in the household. This has, as a consequence, the proliferation of insects and rodents which act as vectors of infectious and parasitic diseases, generating situations which are harmful to health, causing risk to the child development ${ }^{(8)}$. The inadequate dump of the domestic sewage enhances the risks of exposition of the areas of the houses.

The assistance of health of the child is the main reason for the participant to use public transportation. There were reports on the difficulties of access to transportation because of financial difficulties, and P6 reports that she would like to take her child to be assisted closer to her home, because besides being economically more feasible, she would not leave her other daughters alone in the house during the day and she would not spent hours without eating, once she does not have financial condition to buy food in restaurants and snack bars. However, the hospital in her neighborhood does to not offer the service of neurology to assist her son who was born hydrocephalus.

It is common to have the understanding that it 
is enough to make the services of health available and that concomitantly the access to the same happens as a consequence. But, this does not always happen once the access to this service in Brazil is strongly linked to economical and geographical problems, the latter, does not mean only natural geographical difficulties, such as the distance between the house and the venue where the services of health are available, it is also included here the offer of public transportation, the cost and the time of the journey ${ }^{(10-11)}$.

Regarding the devices acquired, only those that the interviewees had the need to buy after the hospital discharge of the child were considered. Among them the following ones are highlighted: thermometer, nebulizer, water filter, sound equipment, blender, iron, dvd player, microwave oven.

When an infant is discharged from a Neonatal Intensive Therapy Care Unit, the infant needs the nebulizer, and can present respiratory problems such as tiredness, cough, wheezing, with indication of use of bronchodilator.

The acquisition of the sound equipment and the dvd player was made by P3, so that in his absence the child could hear recordings of messages left by him and watch interactive videos. The concern of this father is the development of his child, both regarding leaving recording tapes with his voice, so that the child can recognize it, regarding to the use of dvd player which can offer ludic possibilities of learning.

Eight women reported to be brought up in the catholic religion, three were brought up in the protestant religion and only the father was not brought up in any religion. But currently, three women reported to be catholic and two protestant, including the father participant. This means that two are non-practicing catholic, one changed the religion to become protestant, three reported not having any religion and the father currently attends protestant services.

The religion influences in the care and development of the children, once these beliefs often direct the popular care in eating, habits of life and in the health disease process of the child ${ }^{(1,12)}$; so, the women and the father mentioned the search of help through religion, also to raise their children 'in the right way' as P3 and P12 mentioned.

During the interview it was observed that most the participants intend to raise their children in the religion they follow currently. P6 and P7 intend to be practicing catholic persons again to assist their children in Christianity, and P4 and P5 reported that they propose to raise their children in the religion they were brought up: protestant and catholic, respectively. This proves that the meanings of life can be historically transmitted, determining the cultural of a people, through which the mothers and fathers developed their knowledge and activities regarding life. As a social construction, religion provides a way to see the world, experience it cognitively and emotionally, influencing maternal attitudes to raise and stimulate the healthy development of their children ${ }^{(1,12)}$.

Facing the daily habits presented, it is observed that five of them receive alternative care, that is, nonparental types of care ${ }^{(13)}$. Once the babies are under alternative care, especially during the first year of life, controversies have been generated in the scientific environment, once it implies in daily separations of the baby from his mother while he is still too young. Besides that, the interaction mother-child, initially restricted to their homes, where there is more intimacy and exclusivity, is affected when there is a frequent separation of the dyad, affecting the development along the early childhood ${ }^{(13-16)}$.

Analyzing the report of $\mathrm{P} 1$ who choose to leave her child in the nursery it is noticed that the initial motivation was related to the practical dimension, during the period of the day in which the child could not be assisted by her. However, her first choice was the custody of the child in the extended family, leaving the child with the grandmother, indicating that the nursery was a secondary option. However, in her own report a posterior satisfaction is demonstrated, resulting from the choice 'forced'. Another participant, P12, mentioned that she intends to enroll her daughter 
in the nursery, once she believes in the educational character of that institution and in the possibility of socialization that is provided to the children.

The nursery is, in most cases, the option for that woman who feels ambivalent concerning another woman taking care of her child in her own house. When the mother takes the child to the nursery, she is taking the child to an institution, not to another person. There is a difference between having a stranger at home or a stranger in the institution. The stranger at home could be taking care of her child instead of her while the stranger in the nursery would be educating, teaching and not occupying the place of the mother ${ }^{(14-16)}$.

In the case of P3 who lost his wife in the delivery, the choice of the caregiver was even harder. According to him he asked for personal information, address and document of the person who was applying to be the nanny aiming at guaranteeing the safety of the child, once he was afraid of having his child stolen. It is common for the parents to feel insecure and suspicious, especially when this is about his first child, who is still a baby(17).

During the interview it was noticed that the insecurity of even bigger because it would not be a couple who would share the choice, on the contrary, P3 felt totally responsible for the child experiencing feelings such as insecurity when leaving his child to the care of another person. This sensation can be due to the cultural vision in society that the mother has to take care of the children in an exclusive way, and in this case, he was a widower father who could not dedicate himself totally to the child due to the need of work.

What also calls our attention is the behavior of the sleep of the children, both in the day time as well as the night time. It was noticed that seven children had as day activity the act of sleeping, and when observing his night activity it was noticed that this habit can influence the standard of night sleep of four of them. Two of them sleep in the morning and in the afternoon, so this collaborates for the fact that they wake up frequently during the night.

It is important to clarify that we are used to thinking about sleep wrongly from a simplistic activity. Sleep is not simple and it is not well defined and uniform reaction, but on the contrary, it varies according to the individuality of the child and to his maturity. The child has to learn to sleep the same way he learns to crawl, to stand up and to walk. So, because locomotion suffers clear modifications as they grow old, also standards of sleep are modified with maturity(18-20).

In a long term range, the privation of sleep, can seriously jeopardize the health of the child, harming the immunological system, occurring diabetes, cardio vascular and gastro intestine disease, chronic loss of the memory; tendency to develop obesity due to the leptin and ghrelin, hormones which are involved in the control of the satiety and hunger, also linked to sleep ${ }^{(21-22)}$.

It is then apprehended, that the woman-mother organizes her world according to her values and beliefs following the culture in which she is inserted, also reflecting the thought of her peers, in this case, her children. Although the child development progresses in an ordinated manner, it is noticed that the environment influences the development, especially of premature infants. The ability to raise children is not only an instinctive capacity, but a learned and acquired process. The mother cannot learn to do the things that are of her competence, with the care of the child within her cultural dimension only from books, nursing or doctors. She might have learned a lot from the fact of having been a child, and from the observation of other parents with their children and the fact of having helped taking care of her brothers ${ }^{(23)}$.

\section{Final Consideration}

The transcultural perspective allowed to identify characteristics of the social and cultural contexts of the parents (mother and/or father) who had the experience of having premature children, 
as well as try to incentive the work of the nurse in this cultural context, especially when one is dealing with the assistance of the discharged infant from a Neonatal Intensive Care Unit, concerning the child development.

The ethno-nursing as a method allowed along the research the construction of the maternal, social and cultural factors and the child development of infants discharged from a Neonatal Intensive Care Unit, whose support of Atlas-ti software helped in the qualitative analysis, once there is a considerable amount of text data to be analyzed. It is considered that the availability in a growing progress in the production of software has created several opportunities for the advancement of teaching and research in nursing.

\section{Collaborations}

Nazareth IV contributed for the conception, data collection, analysis and writing of the article. Santos IMM contributed for the interpretation, writing of the article and final approval of the version to be published.

\section{References}

1. Boehs AE, Monticelli M, Martins M, Fernandes GCM, Feyer ISS, Rumor PCF. Cultural care theory concepts on master's degree disertations. Rev Rene. 2010; 11(4):182-9.

2. Leininger MM, McFarland MR. Culture care diversity and universality- a worldwide nursing theory. New York: Jones and Bartlett Publishers; 2006.

3. Anjos LS, Lemos DM, Antunes LA, Andrade JMO, Nascimento WDM, Caldeira AP. Maternal perceptions about the birth of a premature child and care after discharge. Rev Bras Enferm. 2012; 65(4):571-7.

4. Medeiros M. Qualitative research approach. Rev Eletr Enferm [periódico na Internet]. 2012 [cited 2013 Feb 20]; 14(2):224-5. Available from: http:// www.fen.ufg.br/revista/v14/n2/v14n2a01.htm
5. Esteban MPS. Introduccíon al programa de análisis de datos cualitativos Atlas-ti 5.0. Barcelona: Universidad de Barcelona; 2009.

6. Silva MDB, Paiva MB, Silva LR, Nascimento MAL. Acute respiratory disease in the child: an integrative review. Rev Enferm UERJ. 2012; 20(2):260-6.

7. Unicef. Child poverty and disparities in Mozambique in 2010. Relatório Sumário. Naputo: Moçambique; 2011.

8. Eyken EDV, Ribeiro CDM. Child development: its agents and the public policies of the city of Rio de Janeiro. Physis. 2012; 22(3):1085-99.

9. Nazareth IV, Santos IMM, Gonçalves APO, Souza ES. Risk for child development according to the integrated attention strategy to the prevalent illnesses in childhood. Rev Enferm UFPE on line [Internet]. 2013 [cited 2013 June 14]; 7(2):2836. Available from: http://www.revista.ufpe.br/ revistaenfermagem/index.php/revista/article/ viewArticle/3376

10. Frota MA, Maia JA, Pereira AS, Nobre CS, Vieira LJES. Reflection on public policies and strategies for child's integral health. Enferm Foco. 2010; 1(3):129-32.

11. Souza ES, Nazareth IV, Gonçalves APO, Santos IMM. A look of women-mothers about prenatal care. Rev enferm UFPE on line [Internet]. 2013 [cited 2013 Oct 24]; 7(8):5135-42. Available from: http://www.revista.ufpe.br/revistaenfermagem/ index.php/revista/article/viewArticle/4562

12. Bousso RS, Serafim TS, Misko MD. The relationship between religion, illness and death in life histories of family members of children with life-threatening Diseases. Rev Latino-Am Enfermagem. 2010; 18(2):11-7.

13. Preuss MRG. Maternal attitudes and type of alternative care chosen for working mothers out. Psic Teor Pesq. 2012; 2(3):213-25.

14. Paz MGT, Alencar EMLS. Family relations and aspects of child socialization in families of professional and non-professional mothers. Psicol Teor Pesqui. 2012; 4(1):69-81.

15. Bandeira TTA, Moura MLS. Mothers and fathers' beliefs about parental investment. Paidéia. 2012; 22(53):355-63. 
16. Araújo MAN, Gama FS, Silva U. Nursery of yesterday and today: what parents expecting that institution? Rev Psicol Diver Saúde. 2013; 1(1):149.

17. Silva JR. The joke in Early Childhood Education (3-5 years): an experience of research and intervention. Educ Rev. 2013; 47(9):340-7.

18. Gaíva MAM, Marquesi MC, Rosa MKO. Sleeping newborn in hospital intensive care unit: nursing care. Ciênc Cuid Saúde. 2010; 9(3):602-9.

19. Weich TM, Ourique AC, Tochetto TM, Franceschi CM. Effectiveness of a noise control program in a neonatal intensive care unit. Rev Bras Ter Intensiva. 2011; 23(3):327-34.
20. Nacleto TS, Louzada FM, Pereira EF. Sleep/wake cycle and the attention deficit/hyperactivity disorder. Rev Paul Pediatr. 2011; 29(3):437-44.

21. Salgado APN, Adirson DM, Cava AM, Camacho KG. Newborn sleep in neonatal intensive care units. Rev Enferm UERJ. 2011; 19(4):644-9.

22. Aurélio FS, Tochetto MT. Noise in a Neonatal Intensive Care Unit: measurement and perception of professionals and parents. Rev Paul Pediatr. 2010; 28(2):162-9.

23. Buccini GS, Tulha MLPA. Maternal care: a health prevention strategy to develop healthy people. Rev Bras Med Fam Comunidade. 2011; 6(20):2036. 